\title{
A COMPARATIVE STUDY OF CONVENTIONAL AND QUASI Z-SOURCE MULTILEVEL INVERTER FOR Photovoltaic Applications
}

\author{
D.Umarani ${ }^{1}$ and Dr.R.Seyezhai ${ }^{2}$ \\ ${ }^{1}$ Assistant Professor, Department of EEE, SSN College of Engineering, Chennai. \\ ${ }^{2}$ Associate Professor, Department of EEE, SSN College of Engineering, Chennai.
}

\begin{abstract}
In this paper, the conventional multilevel inverter (MLI) and Quasi Z-source multilevel inverter are compared for their suitability to Photovoltaic $(P V)$ applications. Five-level cascaded H-bridge configuration has been considered for both the above mentioned inverter topologies. Simulation has been carried for the PV source in Matlab/Simulink and interfaced with the above mentioned multilevel inverter topologies. For the conventional MLI, an additional boost converter stage has been designed and simulated. Impedance network has been designed for the Quasi Z-Source multilevel inverter. The performance of the Quasi Z-Source multilevel inverter has been investigated based on its voltage boost capability with the use of a single converter stage. Also, the additional converter stage required for the conventional MLI for boost operation has been discussed. The suitability of the inverter topology for PV application is analysed by computing the voltage gain, number of converter stages and output power. The results are verified.
\end{abstract}

\section{KEYWORDS}

Multilevel inverter, Photovoltaic, Quasi Z-Source inverter, voltage boost, shoot through.

\section{INTRODUCTION}

The depletion of available non-renewable energy sources for the production of electricity may lead to scarcity in the near future. Before it is completely vanished, we ought to find out a solution that can replace the non-renewable energy source for production of electricity. The better solution will be the use of renewable energy sources such as wind, solar etc., Solar energy based electricity generation is clean and environment friendly. There are several researches going on to efficiently trap the solar energy for generation of electricity. The electricity generated by the solar panel will be a DC quantity. It should be converted to AC for feeding the power grid. So, the inverter plays an important role in the energy conversion. In this paper a five-level cascaded Hbridge configuration of the inverter has been considered. The conventional multilevel inverter (MLI) consists of H-bridges connected in a cascaded way so that the total harmonic distortion of the output may be reduced [8]-[9]. But it has several limitations. In order to overcome the drawbacks, a new topology Quasi Impedance source multilevel inverter has been proposed for PV applications. It has boost capability and voltage inversion in a single stage. Several modulation strategies are available for generation of shoot through states. For the proposed Quasi Z-source multilevel inverter (QZMLI), simple boost control technique is used. The shoot through is added to the pulse width modulation so as to achieve voltage boost [1]-[3]. For the conventional MLI, an additional boost converter stage is required for the same voltage boost as that of the QZMLI. This boost converter is connected to the output of the solar source and then fed to the bridges of

DOI : 10.14810/elelij.2015.4212 
Electrical and Electronics Engineering: An International Journal (ELELIJ) Vol 4, No 2, May 2015

the MLI. The simulation has been carried out using Matlab/Simulink platform and the simulation results are discussed. Section- II explains the mathematical modeling of PV, section-III provides the design specifications of boost converter employed in conventional MLI, section-IV discusses the simulation results for the conventional five-level inverter. The proposed quasi Z-source MLI is discussed in section $-\mathrm{V}$ followed by conclusion.

\section{Mathematical Modeling OF PV}

The PV module has been modeled using mathematical equations is shown in fig.1.The simulation parameters are given in Table 1.

Table 1.PV Simulation Parameters

\begin{tabular}{|l|l|}
\hline PV Parameters & Rating \\
\hline Open circuit voltage Voc & $21.24 \mathrm{~V}$ \\
\hline Short circuit current I sc & $2.55 \mathrm{~A}$ \\
\hline No of cells Ns & 36 \\
\hline Insolation G & $1000 \mathrm{~W} / \mathrm{m} 2$ \\
\hline Ideality factor A & 1.5 \\
\hline Operating temperature T & $298 \mathrm{~K}$ \\
\hline
\end{tabular}


Electrical and Electronics Engineering: An International Journal (ELELIJ) Vol 4, No 2, May 2015

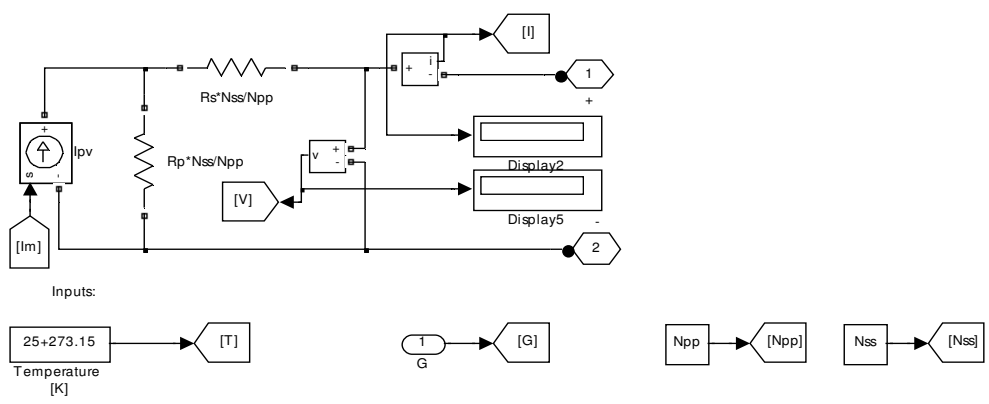

Calculation of Im = Ipv-ld (Nss $\times$ Npp modules):
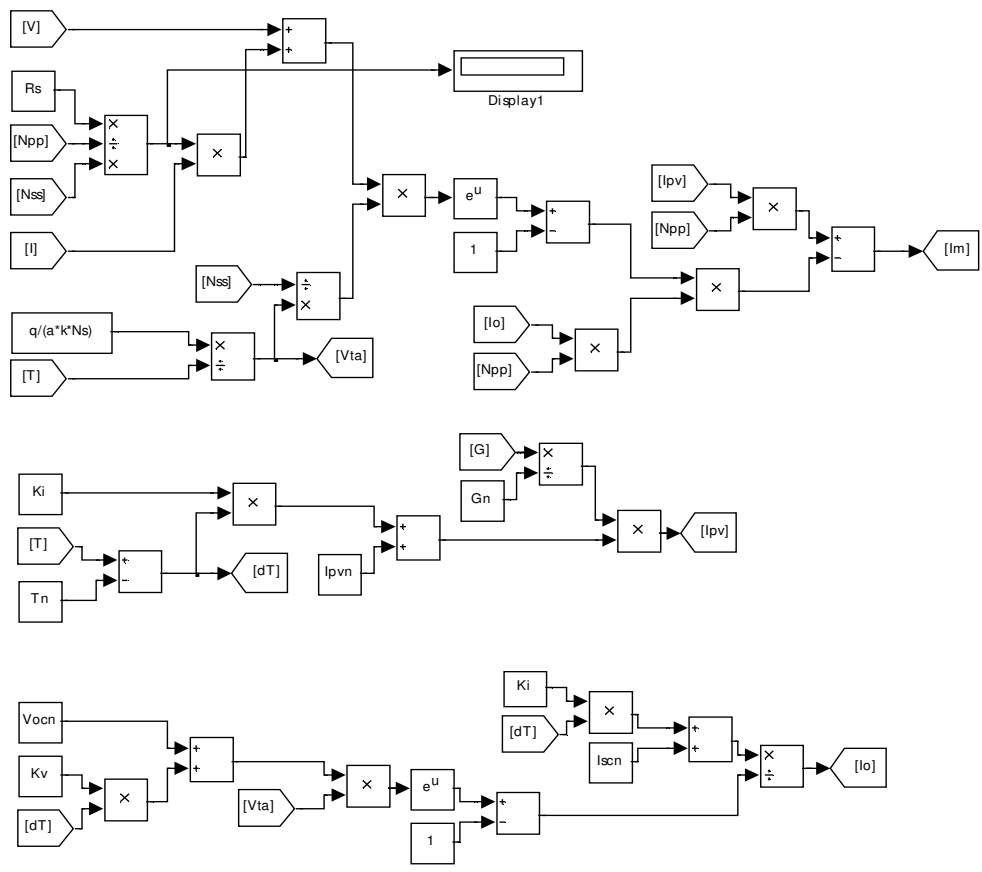

Figure 1. Mathematical modeling of PV module.

The equations used for constructing the PV module are given:

Module's photo-current:

$I_{L}=\left[I_{S C r}+K_{i}(T-298)\right] * \frac{\alpha}{1000}$

Module's reverse saturation current:

$$
l_{r z}-\frac{I_{S C r}}{\left.e^{\frac{Q V I C}{N_{S} K A S}}\right)-1}
$$

Module's saturation current:

$$
I_{u}=I_{T S}\left[\frac{T}{T_{Y}}\right]^{3} e\left[\frac{{ }_{i} F_{g o}}{B \kappa}\left[\frac{1}{T_{T}}-\frac{1}{T}\right]\right.
$$

The output current of the PV module is 


$$
I-N_{P} * I_{L}-N_{p} * I_{0}\left[\exp \left(\frac{q *\left(V_{P V}+I R_{S}\right.}{N_{3} A k T}\right)-1\right]
$$

Where $\mathrm{V}=\mathrm{VOC}, \mathrm{NP}=1$ and $\mathrm{NS}=36$, I is the PV array output current, $\mathrm{V}$ is the PV array output voltage, Ns is the number of cells in series, $\mathrm{Np}$ is the number of cells in parallel, $\mathrm{q}$ is the charge of an electron, $\mathrm{k}$ is the Boltzmann's constant, $\mathrm{A}$ is the $\mathrm{p}-\mathrm{n}$ junction ideality factor, $\mathrm{T}$ is the cell temperature in Kelvin, Irs is the cell reverse saturation current [13].

\section{DESIGN OF BOOST CONVERTER FOR CONVENTIONAL MLI}

The boost converter is required in the conventional MLI when solar energy is used as source for each H-bridge of the MLI. With the use of conventional MLI, the total harmonic distortion may be reduced but the efficiency of energy conversion reduces as an additional converter stage is required. The boosted output has to be fed as input for the conventional MLI.The boost converter specifications are mentioned below. The simulation circuit and the output voltage has been shown in figure 2 and 3.

Input voltage from the PV Source : $21.4 \mathrm{~V}$

Switching frequency $\quad: 10 \mathrm{kHz}$

Inductor L $: 220 \mu \mathrm{F}$

Capacitor C $: 150 \mu \mathrm{H}$

Duty ratio $: 70 \%$

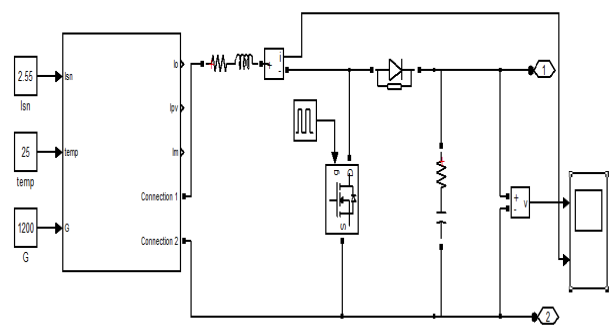

Figure.2 Simulation of Boost Converter

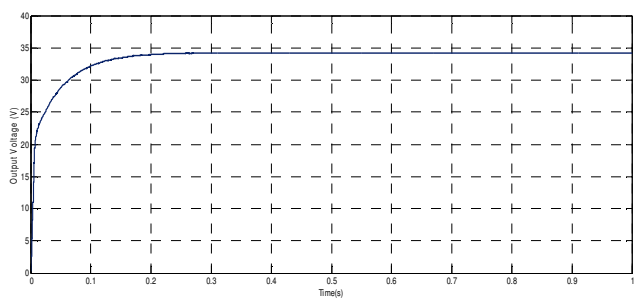

Figure.3 Output voltage of Boost Converter

The output voltage of the boost converter is $34.2 \mathrm{~V}$ which is the boosted voltage from $21.4 \mathrm{~V}$ of the PV.

\section{Simulation OF CONVENTIONAL MLI WiTh PV SOURCE AND BOOST CONVERTER}

The boost converter output has been connected as source to the H-bridge of the Conventional MLI in each of its stage. The MLI topology is considered because by its own circuit configuration high voltage and reduction in harmonics can be achieved. The following are the features of the Cascaded H-bridge MLI. Phase Shifted PWM is used for MLI as it has balanced switching action and reduced Total Harmonic Distortion. Cascaded MLI is preferred for PV as:

- It requires lesser number of circuit components when compared to other MLI topologies.

- Modularized circuit layout is possible because each level has identical structure.

- No clamping diodes and voltage balancing capacitors are required.

- The output voltage is determined by $2 \mathrm{~N}+1, \mathrm{~N}$ - number of DC sources. 
Electrical and Electronics Engineering: An International Journal (ELELIJ) Vol 4, No 2, May 2015

Simulation Parameters for the Conventional MLI is given in Table 2. Simulink model and PWM pulses are given in Figure 4 and 5.

Table 2.Conventional MLI Simulation Parameters

\section{CONVENTIONAL}

\begin{tabular}{|l|l|}
\hline PV Parameters & Rating \\
\hline Input Voltage from Boost Converter & $34.2 \mathrm{~V}$ \\
\hline Switching frequency & $10 \mathrm{kHz}$ \\
\hline Load resistance & $10 \mathrm{ohm}$ \\
\hline
\end{tabular}

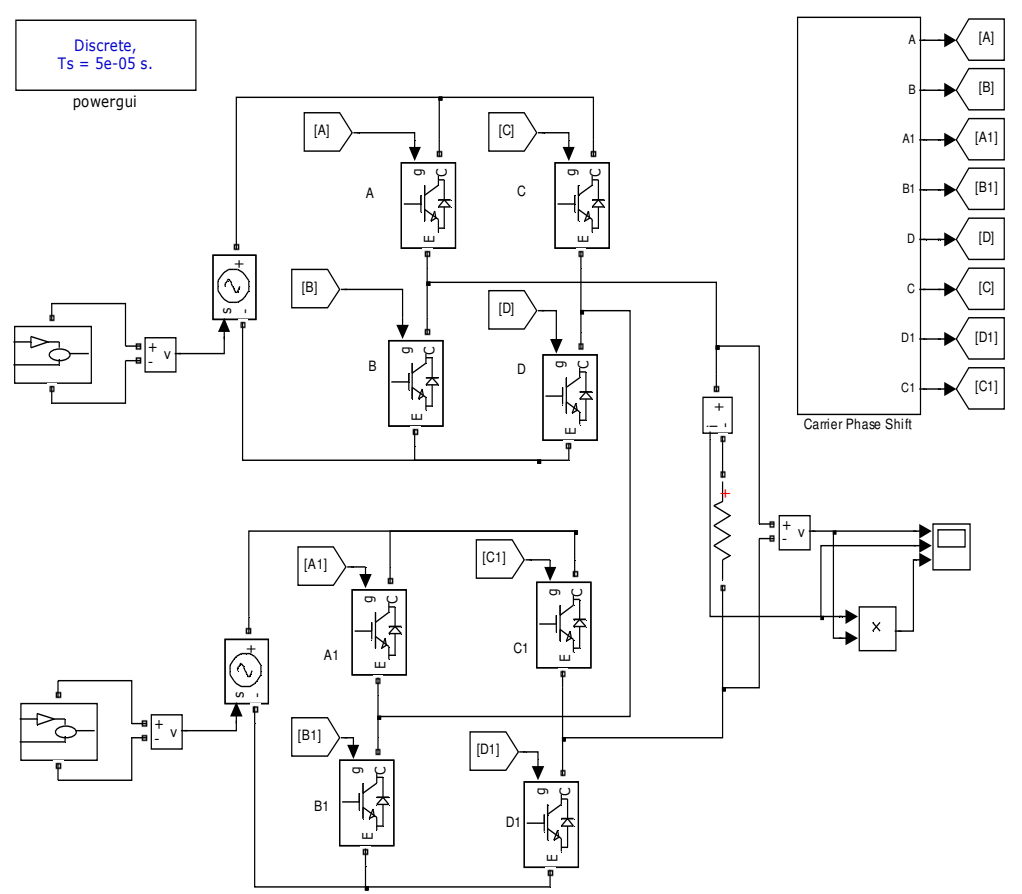

Figure 4. Conventional MLI with PV sourced boost converter

\subsection{PWM Techniques for MLI}

Many pulse-width modulation (PWM) control methods have been devised and utilized for the traditional cascaded multilevel inverter. Following figure shows some of the pulse width modulation (PWM) techniques.For the conventional MLI, all these four PWM techniques have been applied and the results found in terms of total harmonic distortion (THD) is tabulated below. 
Electrical and Electronics Engineering: An International Journal (ELELIJ) Vol 4, No 2, May 2015

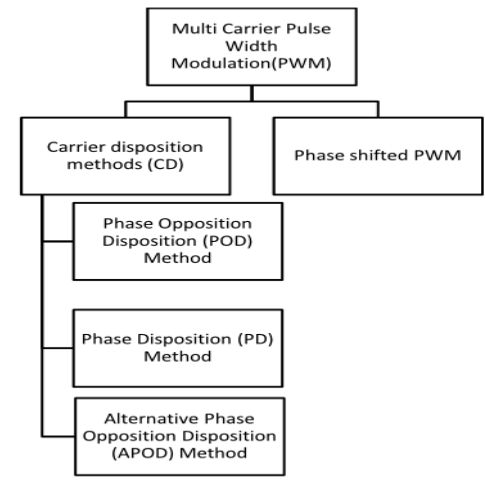

Figure.5 PWM strategies for Multilevel Inverter

Table 3. THD Comparison of Various PWM Strategies

\begin{tabular}{|l|l|l|}
\hline S.No & PWM Technique & THD \% \\
\hline 1 & Phase Disposition & $39.69 \%$ \\
\hline 2 & Phase Opposition Disposition & $45.24 \%$ \\
\hline 3 & Alternate phase opposition disposition & $45.47 \%$ \\
\hline 4 & Carrier phase shift & $40.56 \%$ \\
\hline
\end{tabular}

From this table it is found that the THD is lesser for the PD and Phase shift techniques. Since Phase shift technique has the balanced switching action, it is chosen for the five level QZSI.
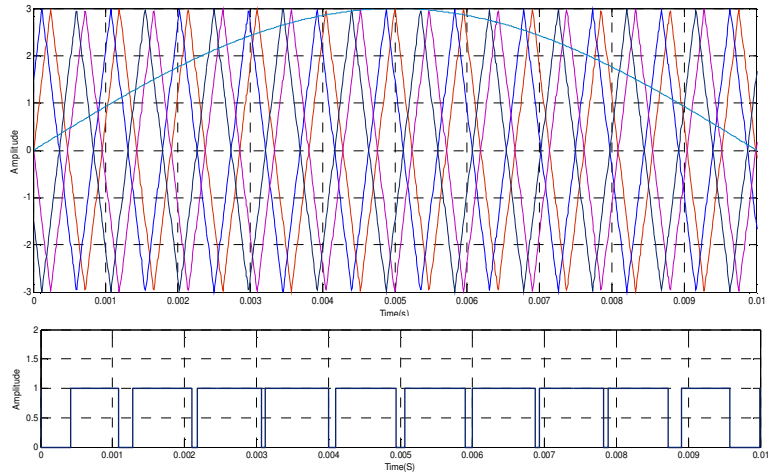

Figure.6 PSPWM for Conventional MLI
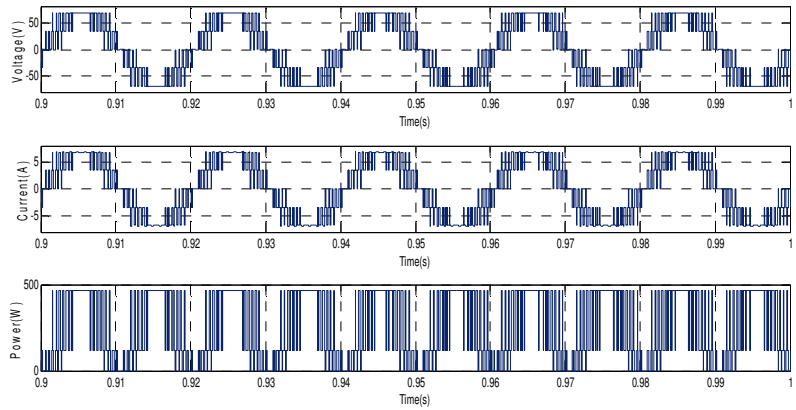

Figure.7 Output Voltage, Current and Power of Conventional MLI 
Electrical and Electronics Engineering: An International Journal (ELELIJ) Vol 4, No 2, May 2015

The cascaded output voltage of the conventional MLI having PV sourced boost converter is found to be $68.4 \mathrm{~V}$. The power consumed by the load is $468 \mathrm{~W}$. It is shown in fig.7

\section{QUASI Z-SOURCE MLI INTERFACED WITH PV}

Conventional MLI has the following limitations:

- The ac output voltage is limited below the dc-rail voltage.

- If overdrive is needed then an additional converter stage is added to obtain the desired output. It increases the system cost and efficiency.

- The upper and lower devices cannot be gated simultaneously as it results in short-circuit with the source and deterioration of devices.

- Dead time is required for triggering both upper and lower devices which results in the distortion of the waveform.

So we go for the Impedance type inverters which can overcome all the disadvantages of conventional MLI. In addition to that these type of inverters can invert as well as boost the voltage in a single stage. These features are value added to the $\mathrm{Z}$-source inverters because of the unique impedance or LC network present as the interface between PV source and the inverter bridge. In this paper, we have discussed the Quasi type impedance inverter as it acquires all the advantages of the Z-source inverter. Also this type of topology has reduced component ratings and improved reliability. Shoot-through is added to the PWM pulses in order to achieve the voltage boosting action. The inverter operates in the shoot-through mode during the shootthrough period. It results in a wide voltage gain [7] - [11]. The impedance network design is shown below.

Inductance:

$$
L_{1}=L_{2}=\frac{\Delta T \cdot V_{2}}{\Delta I}=\frac{T_{0}, m, V_{\text {in }}}{2, I_{L}, R_{G}}
$$

Capacitance:

$$
C_{1}=C_{2}=\frac{2 \cdot \Delta T \cdot I_{1}}{\Delta\left(V_{01}+V_{n 2}\right)}=\frac{T_{0} \cdot m_{1} I_{2}}{2 \cdot B \cdot V_{i n} \cdot R_{v}}
$$

Where,

To - Shoot-through Interval, $\mathrm{m}$ - Modulation Index, Rc - Peak current ripple in \%, Rv - Peak voltage ripple in \%, IL - Rated Load current, fs - Switching frequency. 
Electrical and Electronics Engineering: An International Journal (ELELIJ) Vol 4, No 2, May 2015

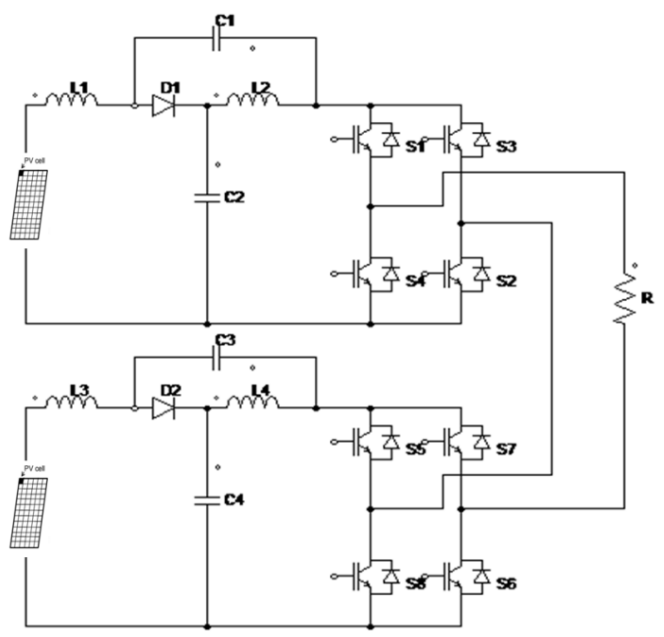

Figure.8 Five-level QZMLI with PV source

Figure. 8 shows the PV sourced five-level cascaded H-bridge QZMLI. Table 4 represents the switching states of the cascaded H-bridge Quasi Z-source multilevel inverter.

Table 4.Switching States of Five-Level QZMLI

\begin{tabular}{|l|l|l|}
\hline Output Voltage & State & ON Switches \\
\hline 2 Vs & Active & S1,S2,S5,S6 \\
\hline Vs & Active & S1,S3,S5,S6 \\
\hline Vs & Shoot-through & S1,S2,S3,S4,S5,S6 \\
\hline Vs & Active & S1,S2,S5,S7 \\
\hline Vs & Shoot-through & S1,S2,S5,S6,S7,S8 \\
\hline 0 & Zero & S1,S3,S5,S7 \\
\hline 0 & Shoot-through & S1,S2,S3,S4,S5,S7 \\
\hline 0 & Shoot-through & S1,S3,S5,S6,S7,S8 \\
\hline- Vs & Active & S1,S3,S7,S8 \\
\hline- Vs & Shoot-through & S1,S2,S3,S4,S7,S8 \\
\hline- Vs & Active & S3,S4,S5,S7 \\
\hline- Vs & Shoot-through & S3,S4,S5,S6,S7,S8 \\
\hline-2 Vs & Active & S3,S4,S7,S8 \\
\hline
\end{tabular}

Table 5.Simulation Parameters of QZMLI

\begin{tabular}{|l|l|}
\hline QZSI Parameters & \multicolumn{1}{c|}{ Rating } \\
\hline Input Voltage per bridge & $21.4 \mathrm{~V}$ \\
\hline Inductors L1,L2 & $5 \mathrm{mH}$ \\
\hline Capacitors C1, C2 & $1150 \mu \mathrm{F}$ \\
\hline Boost Factor B & 1.66 \\
\hline Switching frequency fs & $10 \mathrm{kHz}$ \\
\hline Load resistance RL & $10 \Omega$ \\
\hline
\end{tabular}


Electrical and Electronics Engineering: An International Journal (ELELIJ) Vol 4, No 2, May 2015

There are various shoot-through control techniques available such as Simple boost, Maximum Boost and Maximum Constant Boost control techniques. Simple Boost Control technique is used for the five-level QZMLI. Here we need to compare the carrier and the constant line taken at the maximum value or above the maximum value of the reference wave.

The simulation circuit and pulse generation of the five-level QZMLI is shown in figure.9 and figure.10. The output voltage, current and power of the five-level QZMLI is shown in the figure 11. In this, the phase shifted PWM is implemented to generate the pulses. In order to include the shoot-through states to the PWM pulses, Simple boost control technique is used.

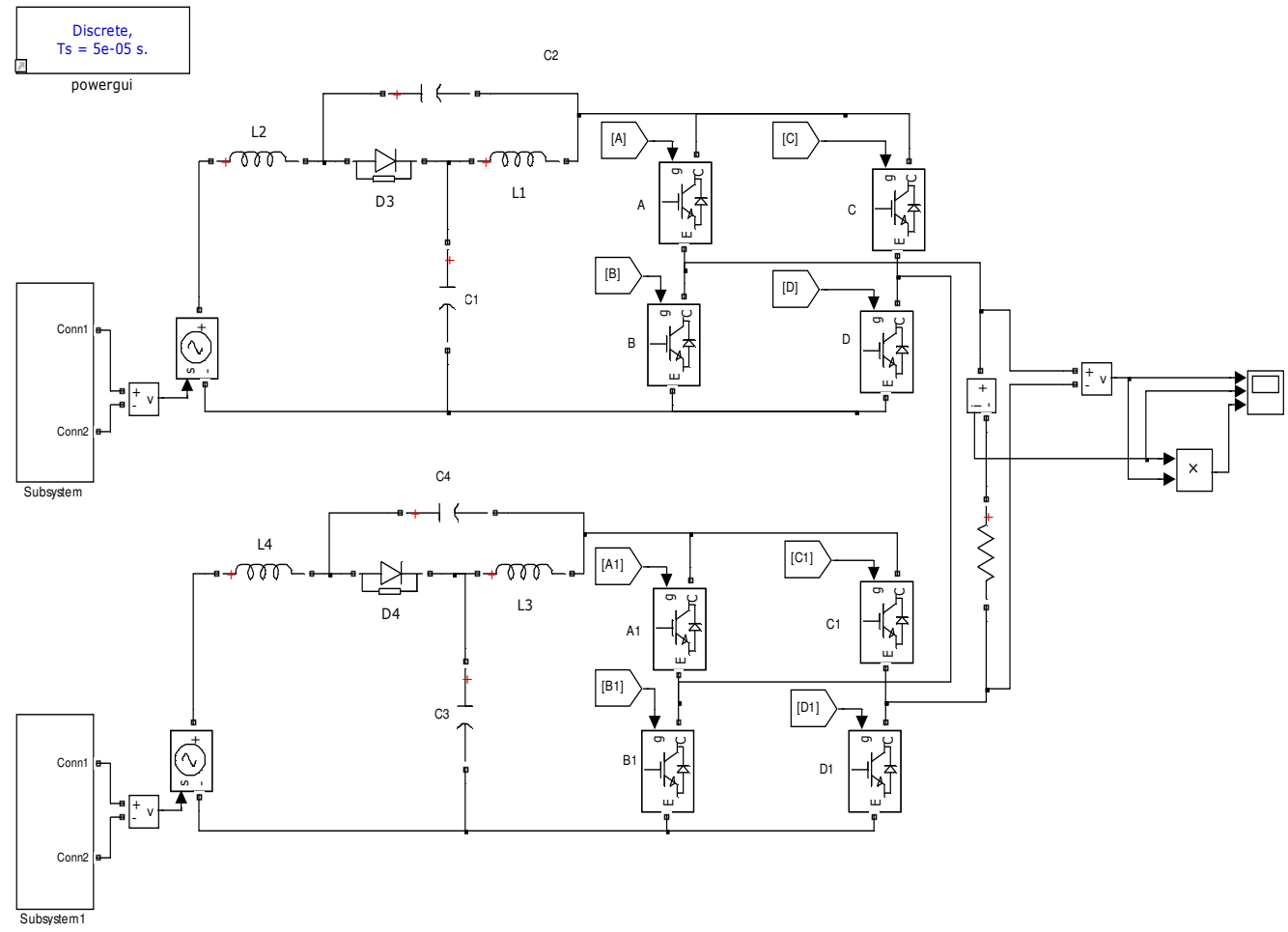

Figure.9 Simulink Model of PV powered QZMLI
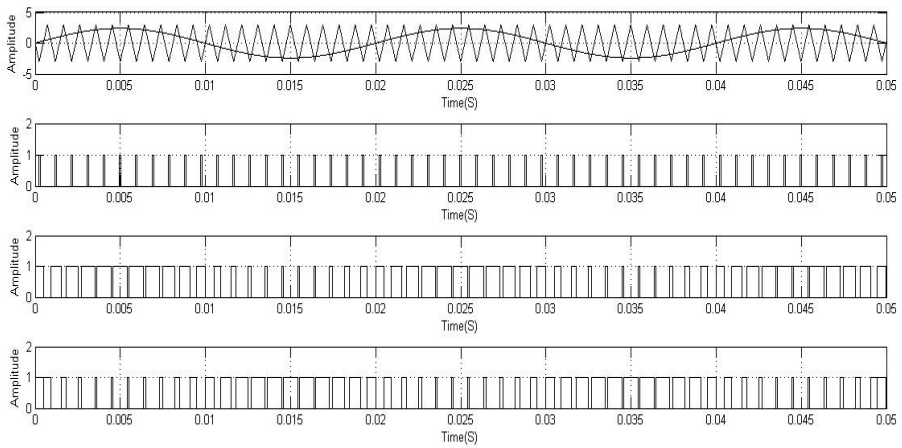

Figure.10 Pulse generation using PSPWM and Simple Boost 

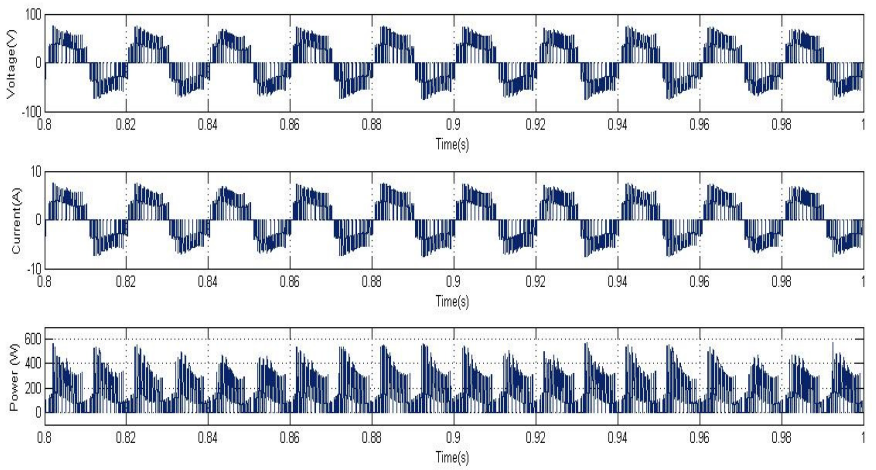

Figure.11 Output voltage, current and power of the five-level QZMLI

The output voltage of the five-level QZMLI for the PV input of 21.4 volt at each stage is $70 \mathrm{~V}$. The output voltage is boosted by the boost factor 1.5. The power consumed by the load is $550 \mathrm{~W}$. The simulation of the conventional five-level MLI and the five-level QZMLI has been carried out using Matlab/Simulink software. The results are shown in Table 6.

Table 6. Simulation Results

\begin{tabular}{|l|l|l|l|l|}
\hline & Input Voltage & Output Voltage & $\begin{array}{l}\text { Voltage } \\
\text { Gain }\end{array}$ & $\begin{array}{l}\text { Power } \\
\text { (W) }\end{array}$ \\
\hline $\begin{array}{l}\text { Conventional MLI } \\
\text { (PV and Boost converter interface) }\end{array}$ & 34.2 for each stage & 68.4 & 1 & 468 \\
\hline $\begin{array}{l}\text { QZMLI } \\
\text { (PV interface) }\end{array}$ & 21.4 for each stage & 70 & 1.63 & 550 \\
\hline
\end{tabular}

From the above table, we can conclude that the voltage and power boosting capability of the QZMLI is far superior to conventional MLI within a single stage avoiding the use of additional converter stage which in turn results in improved reliability, reduced cost and reduced component ratings. Table 7 shows the comparison of simulation carried out for five-level QZMLI and fivelevel conventional MLI under partial shading conditions. Partial shading has been implemented by changing the insolation of the PV source at each H-bridge of the MLI.

Table 7.Simulation Results under Partial Shading

\begin{tabular}{|l|l|l|}
\hline & Voltage Gain & Power(W) \\
\hline Conventional MLI(PV interface) & 0.93 & 53.3 \\
\hline Conventional MLI(PV under partial shading) & 0.86 & 46 \\
\hline QZMLI(PV interface) & 1.54 & 150 \\
\hline QZMLI(PV under partial shading) & 1.47 & 130 \\
\hline
\end{tabular}

From the Table 7, we infer that the voltage gain is almost same for normal as well as in the case of partial shading condition of the PV in five-level QZMLI. But it drastically reduces with the effect of partial shading in the conventional five-level inverter. 
Electrical and Electronics Engineering: An International Journal (ELELIJ) Vol 4, No 2, May 2015

\section{Conclusions}

The simulation has been performed for the five-level cascaded H-bridge conventional inverter with $\mathrm{PV}$ as the source at each $\mathrm{H}$-bridge. For this, PV was modeled using mathematical modeling in Matlab/Simulink. A boost converter was designed with duty ratio $70 \%$ for a switching frequency of $10 \mathrm{kHz}$ to achieve voltage boost in the output of the inverter. The output of the fivelevel conventional MLI was obtained as $68.4 \mathrm{~V}$ for an input of $34.2 \mathrm{~V}$ at each stage of PV interfaced with boost converter. The voltage gain achieved is 1 . But the simulation model of fivelevel cascaded H-bridge Quasi Z-source inverter connected to the same PV source without any boost converter provided an output voltage of $70 \mathrm{~V}$ in a single stage with a voltage gain of 1.63. Thus it indicates we can cut down the cost and improve the efficiency of the inverter. The L and $\mathrm{C}$ components also have reduced ratings in the case of QZSI. The power of the five-level QZMLI is $550 \mathrm{~W}$ which is greater when compared to the $468 \mathrm{~W}$ of the conventional five-level MLI. Also, under the partial shading conditions of the PV module, the boost converter cannot provide a stable voltage to the H-bridges of the conventional MLI. So the output voltage will reduce drastically and it is clearly shown in the simulation results under partial shading. But because of the presence of the impedance network between the PV source and the inverter bridge, the QZMLI has continuous current characteristic. This will not aid in reducing the output voltage because of its operation in shoot-through state. Thus, we can conclude that QZMLI can be efficiently used for photovoltaic applications.

\section{ACKNOWLEDGEMENTS}

The authors would like to thank the All India Council for Technical Education (AICTE) for funding and supporting this project.

\section{REFERENCES}

[1] Baoming Ge ; Abu-Rub, H. ; Fang Zheng Peng ; Qin Lei ; de Almeida, A.T. ; Ferreira, F.J.T.E. ; Dongsen Sun ; Yushan Liu "An Energy Stored Quasi-Z-Source Inverter for Application to Photovoltaic Power System." IEEE Transactions on Industrial Electronics, Volume 60, Issue: 10, Oct. 2013:4468 - 4481 .

[2] Dongsen Sun, Baoming Ge, Fang Zheng Peng, Haitham, A.R., Daqiang Bi ,Yushan Liu "A new gridconnected PV system based on cascaded H-bridge quasi-Z source inverter.", IEEE International Symposium on Industrial Electronics (ISIE), 2012.

[3] S. Thangaprakash, A. Krishnan. "Comparative evaluation of modified pulse width modulation schemes of Z-source inverter for various applications and demands". International Journal of Engineering, Science and Technology, Volume. 2, No. 1, 2010, pp. 103-115

[4] F.Z. Hamidon,P.D. Abd. Aziz,N.H. Mohd Yunus"Photovoltaic Array Modelling with P\&O MPPT Algorithm in MATLAB "), IEEE International Conference on Statistics in Science, Business, and Engineering (ICSSBE), 2012.

[5] J. Anderson and F. Z. Peng, "Four quasi-Z-Source inverters," PESC '08 - 39th IEEE Annual Power Electronics Specialists Conference, June 15, 2008 - June 19, 2008, Rhodes, Greece, 2008, pp. 2743 2749.

[6] Peng, Fang Zheng. "Z-source inverter. " , IEEE Transactions on Industry Applications, Volume 39.2 (2003),pp.504-510.

[7] Y. Li, J. Anderson, F.Z. Peng, and D.C. Liu, "Quasi-Z-source inverter for photovoltaic power generation systems," IEEE Twenty-Fourth Annual Applied Power Electronics Conference and Exposition, APEC 2009, Washington DC, USA, pp. 918-924, 15-19 Feb. 2009.

[8] J. Rodriguez, J.-S. Lai, and F. Z. Peng, "Multilevel inverters: A survey of topologies, controls, and applications," IEEE Transactions on Industrial Electronics, volume 49.4, pp. 724-738, Aug. 2002.

[9] B. P. McGrath and D. G. Holmes, "Multicarrier PWM strategies for multilevel inverters," IEEE Transactions on Industrial Electronics, volume 49, no. 4, pp. 858- 867, Aug. 2002. 
Electrical and Electronics Engineering: An International Journal (ELELIJ) Vol 4, No 2, May 2015

[10] M.Calais, L. J. Borle and V.G. Agelidis, "Analysis of Multicarrier PWM Methods for a Single-phase Five Level Inverter”, IEEE Power Electronics Specialist Conference, PESC'01,July 2001,pp 13511356.

\section{Authors}

D.Umarani received her B.E degree (Electrical and Electronics) in the year 2011 from Mepco Schlenk Engineering College, Sivakasi and M.E in Power Electronics and Drives from SSN College of Engineering in 2014. Currently she an assistant professor at SSN College of Engineering, Chennai. Her areas of interest are Z-Source and Quasi Z-Source inverters.

Dr.R.Seyezhai obtained her B.E. (Electronics \& communication Engineering) from Noorul Islam College of Engineering, Nagercoil in 1996 and her M.E in Power Electronics \& Drives from Shanmugha College of Engineering, Thanjavur in 1998 and Ph.D from Anna University, Chennai, in 2010 . She has been working in the teaching field for about 15 Years. She has published 120 papers in the area of Power Electronics \& Drives. Her areas of interest include SiC Power Devices \& Multilevel Inverters.
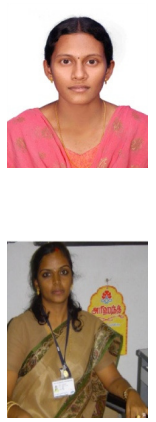